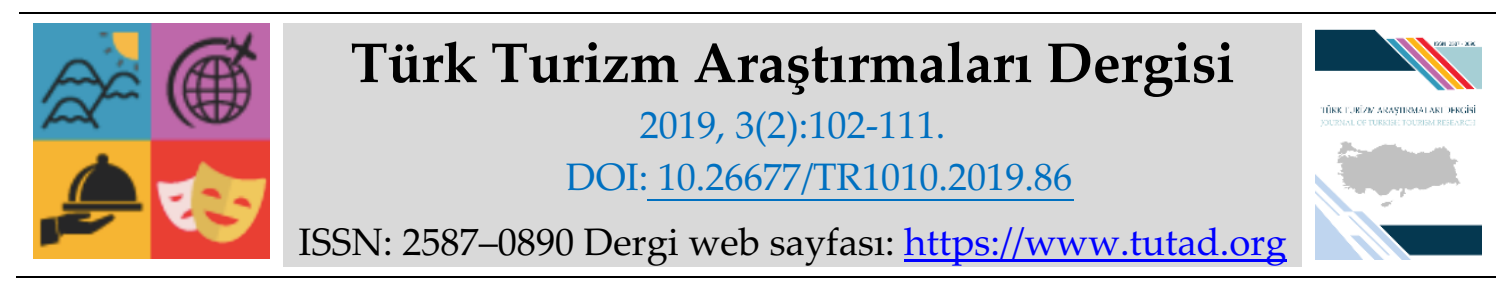

ARAȘTIRMA MAKALESI

\title{
Termal Turizmde Hizmet Kalitesi, Tüketim Duyguları ve Tekrar Ziyaret Niyeti İlişkisi: Balıkesir' de Bir Araştırma*
}

Doç. Dr. Nuran AKŞİT AŞIK, Balıkesir Üniversitesi, Balıkesir Meslek Yüksekokulu, Balıkesir, eposta: nuran@balikesir.edu.tr. ORCID: https://orcid.org/0000-0003-0409-7359

$\ddot{O} z$

Büyük ölçüde deneyim satan termal turizm işletmelerinin hizmet kalitesi, müşterilerin olumlu duygular elde etmesi açısından önemlidir. Çünkü olumlu duygular, müşterileri gelecekte aynı olumlu deneyimi aramaya teşvik edecektir. Bu çalışmanın temel amacı, termal turizmde hizmet kalitesi, tüketim duyguları ve tekrar ziyaret niyeti ilişkisinin incelenmesi ve tekrar ziyaret niyetini en çok etkileyen unsurun araştırılmasıdır. Araştırmada verileri, toplam 400 katılımcıdan yüz yüze anket uygulaması ve kolayda örnekleme yöntemiyle toplanmıştır. Elde edilen veriler, istatistik paket programında, frekans, yüzde, aritmetik ortalama, standart sapma, korelasyon ve regresyon analizi ile çözümlenmiştir. Araştırma bulguları, hizmet kalitesinin pozitif duygular, negatif duygular ve tekrar ziyaret niyeti arasındaki ilişkilerin anlamlı olduğunu ortaya koymaktadır. Ayrıca hizmet kalitesi, pozitif duygular, negatif duygular ve tekrar ziyaret niyeti üzerinde oldukça etkilidir. Araştırmadan elde edilen bulgular, termal turizm müşterilerinin tekrar ziyaret niyeti üzerinde pozitif ve negatif tüketim duygularının hizmet kalitesinden çok daha etkili olduğunu ortaya koymaktadır.

Anahtar Kelimeler: Termal Turizm, Hizmet Kalitesi, Tüketim Duyguları, Tekrar Ziyaret Niyeti. Makale Gönderme Tarihi: 05.11.2018

Makale Kabul Tarihi:.12.03.2019

\section{Önerilen Atıf:}

Akşit Aşık, N. (2019). Termal Turizmde Hizmet Kalitesi, Tüketim Duyguları ve Tekrar Ziyaret Niyeti İlişkisi: Balıkesir'de Bir Araştırma, Türk Turizm Araştırmaları Dergisi, 3(2):102-111.

(C) 2019 Türk Turizm Araştırmaları Dergisi.

\footnotetext{
* Bu makale, 17-21 Ekim 2018 tarihleri arasında, Afyon'da gerçekleştirilen 19. Ulusal Turizm Kongresi'nde sözlü bildiri olarak sunulmuştur.
} 


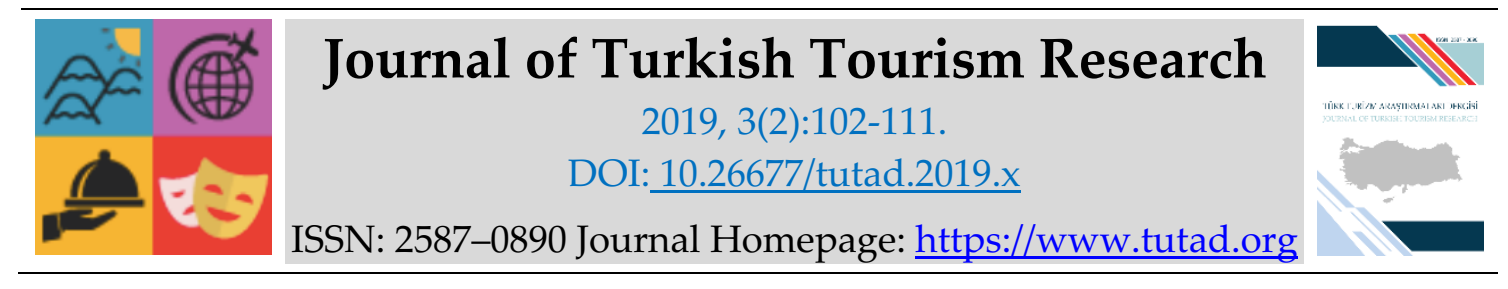

\title{
RESEARCH PAPER
}

\section{The Relationship Between Service Quality, Consumption Emotions and Revisit Intention in Thermal Tourism: A Study in Balıkesir}

Assoc. Dr. Nuran AKŞİT AŞIK, Balıkesir University, Balıkesir Vocational School, Balıkesir, e-mail: nuran@balikesir.edu.tr.

ORCID: https://orcid.org/0000-0003-0409-7359

\begin{abstract}
The thermal tourism enterprises, substantially sell the experience. Hence it is important for thermal tourism enterprises to deliver quality services so that customers attain positive emotions. Because, the positive emotions will encourage to seek the same positive experience in the future. The main purpose of this study is to examine the relation between the quality of service, consumption emotion and revisit intention in thermal tourism, and to investigate the most affecting element on the revisit intention. The research data is collected from 400 participants by face-to-face questionnaire using convenience sampling method. Obtained data is analyzed by using statistical package program with frequency, percentage, arithmetic mean, standard deviation, correlation and regression analysis. The research findings show that the relation between the quality of service, positive emotions, negative emotions, and revisit intention is significantly. In addition, the quality of service is quite effective on positive emotions, negative emotions and revisit intention. The findings obtain from the research reveal that the effect of the positive and negative consumption emotions on the revisit intention are higher than the service quality.
\end{abstract}

Keywords: Thermal Tourism, The Quality of Service, Consumption Emotion and Revisit Intention.

Received: 05.11.2018

Accepted: 12.03 .2019

\section{Suggested Citation:}

Akşit Aşık, N. (2019). The Relationship Between Service Quality, Consumption Emotions and Revisit Intention in Thermal Tourism: A Study in Balıkesir, Journal of Turkish Tourism Research, 3(2):102-111.

(C) 2019 Türk Turizm Araştırmaları Dergisi. 


\section{Gíriş}

Son yıllarda termal turizmde yaşanan hızlı gelişme ve termal turizm işletmelerine olan talep artışı ciddi bir rekabet ortamını da beraberinde getirmiştir. Bu durum, rekabet üstünlüğü sağlamak isteyen termal turizm işletmelerini farklı arayışlara yönlendirmiş, tüketicilerin istek ve beklentilerine daha fazla önem vermelerine neden olmuştur. Bu nedenle müşteri memnuniyetini ve pazar payını arttırmak isteyen termal turizm işletmeleri açısından hizmet kalitesi, vazgeçilmez bir rekabet unsuru haline gelmiştir.

Termal turizm işletmelerinin, sadece sağlık, konaklama, yeme-içme ve rekreasyon hizmeti gibi fiziksel unsurlara önem vermesi yeterli değildir. Aynı zamanda sunulan ürün ve hizmete, müşterilerin verdiği duygusal tepkilerin de değerlendirilmesi gerekir. Termal turizm işletmelerine dinlenmek, eğlenmek, rahatlamak ve kendilerini daha sağlıklı hissetmek amacıyla giden insanlara sunulan hizmetin, söz konusu beklentileri karşılaması, müşterilerin olumlu duygusal tepkiler vermesini sağlayacaktır. Ayrıca hizmet deneyimlerinin müşteriler üzerinde olumlu duygular uyandırmasının kalite algısı, memnuniyet ve tekrar ziyaret niyeti açısından önemli olduğu düşünülmektedir.

$\mathrm{Bu}$ araştırmanın temel amacı, hizmet kalitesi, pozitif ve negatif tüketim duyguları ile tekrar ziyaret niyeti arasındaki ilişkilerin incelenmesidir. Tekrar ziyaret niyetini en çok etkileyen unsurun belirlenmesi, araştırmanın bir diğer amacını oluşturmaktadır. Hizmet kalitesi, tüketim duyguları ve gelecek davranışlarını birlikte ele alan ve bu araştırmayla kısmen benzerlik gösteren tek çalışma Lo vd., (2018) tarafından yapılmıştır. Dolayısıyla, hizmet kalitesi, pozitif ve negatif tüketim duyguları ile tekrar ziyaret niyetinin birlikte ele alındığı çalışmanın, bu açıdan önemli olduğu düşünülmekte, araştırma sonuçlarının ilgili yazına ve uygulayıcılara katkı sağlaması beklenmektedir.

\section{KAVRAMSAL ÇERÇEVE}

İnsanların yüzyıllardır çeşitli rahatsızlıklarını gidermek için termal su kaynaklarından yararlanma düşüncesi gelenek haline gelmiştir (Timur, 2015: 3). Ancak, termal tesislerin son yıllarda zindeleşme, güzelleşme, rahatlama, dinlenme ve sağlıklı kalma amacıyla kullanılması, termal turizm talebinin ve tesis sayısının hızla artmasına neden olmuştur (Türksoy ve Türksoy, 2010: 704). Bunun sonucu olarak ortaya çıkan rekabet ortamı, termal turizm işletmelerinin, rakiplerin taklit edemeyeceği benzersiz deneyimler sunmasını ve hizmet kalitesini arttırmasını zorunlu hale getirmiştir.

Tüketici deneyimlerinin doğru bir şekilde anlaşılabilmesi ve rekabet avantajı sağlaması bakımından büyük önem taşıyan hizmet kalitesi, kısaca "müşterinin aldığı hizmete ilişkin algısını, beklentileri ile karşılaştırdığı bir değerlendirme sürecinin çıktısı" olarak tanımlanmaktadır (Ataman vd., 2011: 74). Tüketicilerin ürün ya da hizmete ilişkin deneyimleri sonucu ortaya çıkan ve bireyden bireye farklılık gösteren bilişsel değerlendirmelere dayanan hizmet kalitesi, tüketim duygularının önemli bir belirleyicisidir (Murat ve Çelik, 2007; Çatı ve Baydaş, 2008; Kılıç ve Eleren, 2009).

Bir ürün ya da hizmeti değerlendirirken, satın alırken ya da kullanırken yaşanan öznel duygular olarak tanımlanan tüketim duyguları, pozitif ve negatif olmak üzere iki düzeyde incelenmektedir (Richins, 1997; King ve Meiselman, 2010). Beklenti sonrasında ve tatmin öncesinde ortaya çıkan tüketim duyguları, tüketicilerin hafızalarını, düşünce süreçlerini, güdülenmelerini, tatmin algılarını ve bir sonraki tüketim deneyimini yönlendiren en önemli unsurlardan biridir (Phillips ve Baumgartner, 2002; Matilla ve Ro, 2007). 
Yapılan literatür taramasında, hizmet kalitesi ve tekrar ziyaret niyeti ilişkisini araştıran çok sayıda araştırmaya rastlanmıştır (Duman ve Öztürk, 2005; Alexandris vd, 2006; Jang ve Feng, 2007; Chi ve Qu, 2008; Organ ve Soydaş, 2012). Bu araştırmalardan elde edilen sonuçlar, hizmet kalitesinin, tüketicilerin tekrar satın alma ve tekrar ziyaret niyetlerini olumlu etkilediğini göstermektedir. Bazı çalışmalarda hizmet kalitesi, tekrar satın alma niyetinin güvenilir bir öngörücüsü olarak nitelendirilmektedir (Cronin vd, 2000; Cho vd, 2004).

\section{YÖNTEM}

$\mathrm{Bu}$ çalışma, betimleyici araştırma yöntemlerinden, ilişkisel tarama modeli kullanılarak gerçekleştirilmiştir.

\section{Evren ve Örneklem}

Araştırmanın evrenini, bir termal turizm işletmesinde en az bir hafta konaklayan yerli turistler oluşturmaktadır. Evrenin tamamına ulaşmak mümkün olmadığı için, Balıkesir'de faaliyet gösteren turizm işletme belgeli 8 termal otelin (www.balikesirkulturturizm.gov.tr) müşterileri çalışma evreni olarak seçilmiştir. Söz konusu otellerin yatak kapasiteleri üzerinden yapılan örneklem hesaplaması sonucunda, en az 384 kişiye ulaşılması gerektiği belirlenmiştir. Bu doğrultuda kolayda örnekleme yöntemiyle belirlenen 400 kişiye yüz yüze görüşme yöntemiyle anket uygulanmıştır. Uygulama 21 Mart-14 Mayıs 2018 tarihleri arasında araştırma yöntemleri eğitimi almış yedi öğrencinin yardımıyla gerçekleştirilmiştir.

\section{Verilerin Toplanması}

Araştırma verileri, dört bölümden oluşan anket formu aracilığıyla toplanmıştır. Birinci bölüm katılımcıların demografik ve diğer özelliklerini sorgulayan 7 soru içermektedir. İkinci bölüm hizmet kalitesi (34 madde), üçüncü bölüm tüketim duyguları (10 madde) ve dördüncü bölüm tekrar ziyaret niyeti (2 madde) ile ilgili önermelerden oluşmaktadır.

Araştırmada kullanılan hizmet kalitesi ölçeği daha önce yapılan çalışmalardan (Duman ve Öztürk, 2005; Alén vd., 2006; Aşık, 2016; Örnek ve Albayrak, 2017) ortak maddeler seçilerek oluşturulmuştur. Tüketim duygularını ölçmek için Richins (1997) tarafından geliştirilen tüketim duyguları ölçeğinden yararlanılmıştır. Ölçeğin hizmet kalitesini ölçmeye elverişli olmadığı düşünülen (mahcup olma, kıskançlık, utanma, cesaret vb.) yedi maddesi kapsam dışı bırakılmış, beş pozitif ve beş negatif duygu kullanılmıştır. Tekrar ziyaret niyeti ise kısa (bir yıl) ve uzun vadede (beş yıl) tesise tekrar gelme durumunu sorgulayan iki madde ile ölçülmüştür.

Önermelere tepki kategorileri 5'li Likert derecelemesine (hizmet kalitesi ve tekrar ziyaret niyeti için 1= Hiç Katılmıyorum, 5=Tamamen Katılıyorum; tüketim duyguları için 1= Hiçbir Zaman, 5= Her Zaman) tabi tutulmuştur. Anket formu hazırlandıktan sonra, 41 kişi üzerinde pilot uygulama yapılmış ve gelen eleştiriler doğrultusunda anket formu tekrar düzenlenerek uygulama aşamasına geçilmiştir.

\section{Verilerin Analizi}

Araştırma verilerinin analizinde frekans, yüzde, ortalama ve standart sapma gibi betimleyici istatistiklerin yanı sıra Pearson korelasyonu ve regresyon analizinden yararlanılmıştır. Tüm 
veriler $\mathrm{p}<, 05$ anlamlılık düzeyinde test edilmiştir. Ölçeklerin yapı geçerliği için açıklayıcı faktör analizinden yararlanılmıştır.

\section{BULGULAR}

\section{Faktör Analizi, Ortalama ve Standart Sapma Bulguları}

Tablo 1'de hizmet kalitesi ölçeğine uygulanan faktör analizi sonuçları verilmektedir. Temel bileşenler analizi ve varimax döndürme sonucu KMO değeri \%89,6 bulunmuş ve Bartlett küresellik testi $\left(X^{2}=9990,9 ; \mathrm{p}<, 00\right)$ ile maddeler arasında anlamlı korelasyonlar olduğu belirlenmiştir. Faktör analizi sonrası hizmet kalitesi ölçeği öz değeri 1'den büyük ve toplam varyansın \%64,35'ini açıklayan yedi boyuta ayrılmıştır. Yapılan güvenilirlik analizinde, ölçeğin iç tutarlılık katsayısı olarak Cronbach's Alfa değeri 0,90 olarak hesaplanmıştır. Buna göre ölçeğin yüksek derecede güvenilir olduğu tespit edilmiştir (Kalaycı, 2014: 405)

Tablo 1. Hizmet Kalitesi Ölçeğine Ait Faktör Analizi, Ortalama ve Standart Sapma Bulguları

\begin{tabular}{lccccc}
\hline Faktörler & $\bar{X}$ & S.S. & Özdeğer & A. Vary. & C. Alfa \\
\hline F1. Fiziksel Özellikler & 4,02 &, 669 & 10,015 & 28,61 &, 78 \\
F2. Çalışan Davranışları & 3,96 &, 534 & 5,266 & 15,04 &, 71 \\
F3. Tibbi Hizmetler & 4,21 &, 543 & 2,431 & 6,95 &, 77 \\
F4. Özel İlgi & 3,91 &, 563 & 1,433 & 4,09 &, 74 \\
F5. Yiyecek ve İçecek Hiz. & 3,37 &, 991 & 1,184 & 3,38 &, 69 \\
F6. Fiyat & 3,63 &, 597 & 1,144 & 3,27 &, 63 \\
F7. Temizlik ve Hijyen & 3,43 &, 983 & 1,052 & 3,01 &, 66 \\
Tüm Ölçek & 3,88 &, 658 & & 64,35 &, 90 \\
\hline
\end{tabular}

Temel Bileşenler Analizi, Varimax Döndürme

KMO:,896; $x^{2}=9990,884 ; p \leq, 000$

Tablo 1'de hizmet kalitesi boyutlarının aritmetik ortalamaları ve standart sapmaları yer almaktadır. Buna göre ortalaması en yüksek hizmet kalitesi boyutu tıbbi hizmetlere $(\bar{x}=4,21)$, ortalaması en düşük hizmet kalitesi boyutu ise yiyecek-içecek hizmetlerine $(\bar{x}=3,37)$ aittir. Tüm ölçeğe ait hizmet kalitesi ortalaması $(\bar{x}=3,88)$ değerlendirildiğinde, katılımcıların hizmet kalitesi algısının iyi düzeye yakın olduğu belirlenmiştir. Bu sonuç, gerek müşteriler gerekse araştırmanın yapıldığı işletmeler açısından olumlu olarak nitelendirilebilir.

Tablo 2. Tüketim Duyguları Ölçeğine Ait Faktör Analizi, Ortalama ve Standart Sapma Sonuçları

\begin{tabular}{lcccccc}
\hline Ölçekler & $\bar{X}$ & S.S. & KMO & $X^{2}$ & A. Var. & C. Alfa \\
\hline Pozitif Duygular & 4,01 &, 489 &, 788 & 154,223 & 72,89 &, 72 \\
Negatif Duygular & 2,85 &, 634 &, 708 & 131,194 & 73,09 &, 76 \\
Tekrar Ziyaret Niyeti & 3,82 &, 526 & & & &
\end{tabular}

Tüketim duyguları ölçeğine ilişkin faktör analizi bulguları Tablo 2'de görülmektedir. Pozitif duygulara ait KMO değeri \%78,8, negatif duygulara ait KMO değeri \%70,8 olarak hesaplanmış ve Bartlett küresellik testi sonuçlarına $\left(X^{2}=154,223 ; X^{2}=131,194 ; \mathrm{p}<, 00\right)$ göre, maddeler arasındaki korelasyonun anlamlı olduğu belirlenmiştir. Ayrıca Chronbach's Alfa değeri pozitif duygular için 0,72 , negatif duygular için 0,76 olarak hesaplanmıştır. Elde edilen sonuçlar, iki ölçeğin de iyi düzeyde güvenilir olduğunu ortaya koymaktadır.

Tablo 2 incelendiğinde, katılımcıların konaklama süresi boyunca yaşadıkları pozitif duyguların $(\bar{x}=4,01)$ negatif duygulara $(\bar{x}=2,85)$ göre daha yüksek olduğu belirlenmiştir. Ayrıca araştırmaya katılanların tekrar ziyaret niyeti ortalamasının $(\bar{x}=3,82)$ iyi düzeye yakın olması, katılımcıların pozitif duygularının daha yüksek olmasını destekler niteliktedir. 
Araştırmaya katılanların demografik ve diğer özelliklerine ait bulgular Tablo $3^{\prime}$ te verilmektedir. Buna göre katılımcıların \%45'i kadın, \%55'i erkektir. \%66,5'i evli olan katılımcıların \%33'ü ortaöğretim mezunu olup, \%27,3'ü 56 yaşından büyüktür. Katılımcıların \%27'si 3001-4500 TL aylık ortalama gelire sahiptir. Ayrıca \%27,7'si özel sektörde çalışmakta ve \%33,5'i romatizmal hastalıklardan yakınmaktadır.

Tablo 3. Katılımcıların Sosyo-Demografik Özelliklerine Göre Dağılımı ( $\mathrm{n}=400)$

\begin{tabular}{|c|c|c|c|c|c|}
\hline Değişkenler & $\mathbf{f}$ & $\%$ & Değişkenler & $\mathrm{f}$ & $\%$ \\
\hline Cinsiyet & & & Eğitim Durumu & & \\
\hline Kadın & 180 & 45 & İlköğretim & 76 & 19,0 \\
\hline Erkek & 220 & 55 & Ortaöğretim & 132 & 33,0 \\
\hline Medeni Durum & & & Ön Lisans & 83 & 20,7 \\
\hline Bekâr & 134 & 33,5 & Lisans & 107 & 26,8 \\
\hline Evli & 266 & 66,5 & Lisans Üstü & 2 & 0,5 \\
\hline Yaş & & & Gelir Düzeyi & & \\
\hline 18- 25 Yaş & 54 & 13,4 & 1500 TL'den az & 39 & 9,7 \\
\hline 26- 35 Yaş & 73 & 18,3 & $1501-3000 \mathrm{TL}$ & 63 & 15,8 \\
\hline 36- 45 Yaş & 77 & 19,3 & 3001-4500 TL & 108 & 27,0 \\
\hline 46- 55 Yaş .. & 87 & 21,7 & $4501-6000 \mathrm{TL}$ & 107 & 26,7 \\
\hline 56 Yaş ve Üzeri & 109 & 27,3 & 6001 TL ve Üzeri & 83 & 20,8 \\
\hline Meslek/Meşguliyet & & & Tesise Geliş Amacı & & \\
\hline Öğrenci & 30 & 7,5 & Romatizmal Has. & 134 & 33,5 \\
\hline Özel Sektör Çal. & 111 & 27,7 & Kas-İskelet Sis. Has. & 83 & 20,8 \\
\hline Ev Hanımı & 44 & 11,0 & Dinlenme ve Sağlık & 115 & 28,7 \\
\hline Kamu Çalışanı & 96 & 24,0 & Böbrek Hastalıkları & 43 & 10,7 \\
\hline Emekli & 60 & 15,0 & Cilt Hastalıkları & 12 & 3,0 \\
\hline Serbest Meslek & 53 & 13,3 & Mide- Barsak Hast. & 8 & 2,0 \\
\hline Diğer & 6 & 1,5 & Diğer Hastalıklar & 5 & 1,3 \\
\hline
\end{tabular}

\section{Korelasyon ve Regresyon Analizi Bulguları}

Tablo 4. Hizmet Kalitesi Faktörleri, Tüketim Duyguları ve Tekrar Ziyaret Niyeti İlişkisine Ait Korelasyon Analizi Bulguları

\begin{tabular}{lccc}
\hline Faktörler & Pozitif Duygular & $\begin{array}{c}\text { Negatif } \\
\text { Duygular }\end{array}$ & Tekrar Ziyaret Niyeti \\
\hline Fiziksel Özellikler &, $450^{* *}$ &,$- 422^{* *}$ &, $563^{* *}$ \\
Çalışan Davranışları &, $621^{* *}$ &,$- 469^{* *}$ &, $529^{* *}$ \\
Tibbi Hizmetler &, $723^{* *}$ &,$- 440^{* *}$ &, $695^{* *}$ \\
Özel İlgi &, $541^{* *}$ &,$- 187^{* *}$ &, $301^{* *}$ \\
Yiyecek ve İçecek Hizmeti &, $315^{* *}$ &,$- 425^{* *}$ &, $451^{* *}$ \\
Fiyat &, $619^{* *}$ &,$- 426^{* *}$ &, $568^{* *}$ \\
Temizlik ve Hijyen &, $520^{* *}$ &,$- 447^{* *}$ &, $446^{* *}$ \\
\hline
\end{tabular}
$* * \mathrm{p}<, 01$

Tablo 4'te verilen korelasyon analizi bulguları incelendiğinde, termal turizm işletmelerinin hizmet kalitesi faktörleri, pozitif ve negatif tüketim duyguları ile tekrar ziyaret niyeti arasında istatistiksel olarak anlamlı $(\mathrm{p}<, 01)$ bir ilişki olduğu görülmektedir. Buna göre, hizmet kalitesi faktörlerinden tıbbi hizmetler ile pozitif duygular arasında yüksek $(\mathrm{r}=, 723)$, çalışan davranışları $(\mathrm{r}=, 621)$, fiyat $(\mathrm{r}=, 619)$, özel ilgi $(\mathrm{r}=, 541)$, temizlik ve hijyen $(\mathrm{r}=, 520)$ faktörleri arasında ise orta düzeyde ve doğrusal bir korelasyon söz konusudur.

Hizmet kalitesi faktörleri ile negatif duygular arasında zıt yönlü ve zayıf bir korelasyon vardır. ile Negatif duygularla en yüksek korelasyon çalışan davranışlarına $(r=-, 469)$ aittir. Tıbbi 
hizmetlerle tekrar ziyaret niyeti arasında, yüksek düzeyde $(\mathrm{r}=, 695)$, fiyat $(\mathrm{r}=568)$, fiziksel özellikler $(r=, 563)$ ve çalışan davranışları ile $(r=, 529)$ tekrar ziyaret niyeti arasında ise orta düzeyde doğrusal bir korelasyon göze çarpmaktadır.

Tablo 5. Hizmet Kalitesinin, Tüketim Duyguları ve Tekrar Ziyaret Niyetini Açıklama Düzeyine İlişkin Regresyon Analizi Bulguları

\begin{tabular}{lcccccc}
\hline Bağımlı Değişken & R & D.R & F & $\beta$ & t & Sig. \\
\hline Pozitif Tüketim Duy. &, 78 &, 60 & 598,730 &, 78 & 24,469 &, $000^{*}$ \\
Negatif Tüketim Duy. &, 52 &, 27 & 148,497 &,- 52 & $-12,186$ &, $000^{*}$ \\
Tekrar Ziyaret Niyeti &, 72 &, 52 & 432,709 &, 72 & 20,802 &, $000^{*}$ \\
\hline p<,01 & & & & & &
\end{tabular}

Tablo 5'e göre, hizmet kalitesi, pozitif tüketim duygularına ait toplam varyansın \%60'ını açılamaktadır (D.R2=,60; $F=598,730 ; p<, 01$ ). Elde edilen sonuç, hizmet kalitesi ile pozitif tüketim duyguları arasında doğrusal bir ilişki olduğunu $(\beta=, 78 ; p<, 01)$ ve hizmet kalitesindeki bir birimlik artışın, pozitif tüketim duygularını \%78 arttırdığını göstermektedir.

Negatif tüketim duygularına ait toplam varyansın \%27'sini açıklayan (D.R $2=, 27 ; F=148,497 ; p<, 01$ ) hizmet kalitesi ile negatif tüketim duyguları arasında zıt yönlü bir ilişki bulunmaktadır. Buna göre hizmet kalitesindeki bir birimlik artış, negatif tüketim duygularını $\% 52$ azaltmaktadır $(\beta=-$ ,52; $\mathrm{p}<, 01)$.

Hizmet kalitesi, tekrar ziyaret niyetine ait toplam varyansın \%52'sini açıklamaktadır (D.R ${ }^{2}=, 52$; $\mathrm{F}=432,730 ; \mathrm{p}<, 01)$. Elde edilen bulgular, hizmet kalitesindeki bir birimlik artışın, tekrar ziyaret niyetini \%72 arttırdığını ortaya koymaktadır $(\beta=, 72 ; p<, 01)$.

Tablo 6. Hizmet Kalitesi, Pozitif Tüketim Duyguları ve Negatif Tüketim Duygularının Tekrar Ziyaret Niyetini Açıklama Düzeyine İlişkin Çoklu Regresyon Analizi Bulguları

\begin{tabular}{|c|c|c|c|c|c|}
\hline Bağımsız Değişkenler & B & Std. H. & $\beta$ & $\mathrm{t}$ & Sig. \\
\hline Sabit & 1,915 & ,208 & & 9,189 &, $000^{*}$ \\
\hline Hizmet Kalitesi & 185 & ,046 & 15 & 4,014 &, $000^{*}$ \\
\hline Pozitif Duygular & ,558 & ,044 &, 52 & 12,663 &, $000^{*}$ \\
\hline Negatif Duygular & -231 & ,022 &,- 32 & $-10,663$ &, $000^{*}$ \\
\hline
\end{tabular}

Tablo 6'ya göre, hizmet kalitesi ve pozitif tüketim duyguları ile tekrar ziyaret niyeti arasında anlamlı ve doğrusal bir ilişki, negatif tüketim duyguları ile tekrar ziyaret niyeti arasında ise anlamlı ve zıt yönlü (D.R²=,77; F=462,674; p<,01) bir ilişki söz konusudur. Üç bağımsız değişken birlikte, tekrar ziyaret niyetine ait toplam varyansın \%77'sini açıklamaktadır. Standardize edilmiş regresyon katsayılarına göre, bağımsız değişkenlerin tekrar ziyaret niyeti üzerindeki etkisine yönelik, göreli önem sırasının, pozitif duygular $(\beta=, 52 ; \mathrm{p}<, 01)$, negatif duygular $(\beta=-, 32 ; \mathrm{p}<, 01)$ ve hizmet kalitesi $(\beta=, 15 ; \mathrm{p}<, 01)$ olduğu görülmektedir.

\section{TARTIŞMA, SONUÇ VE ÖNERİLER}

Balıkesir'de faaliyet gösteren termal otellerde gerçekleştirilen araştırmanın bulguları, araştırmaya katılanların hizmet kalitesi algılarının iyi düzeye yakın olduğunu ve müşterilerin termal turizm işletmelerinde konakladıkları süre boyunca pozitif duygularının daha yüksek olduğunu göstermektedir. Ayrıca araştırmaya katılanların tekrar ziyaret niyeti ortalamalarının da oldukça yüksek olduğu belirlenmiştir. 
Müşterilerin hizmet kalitesi faktörlerine ilişkin kalite algıları incelendiğinde, en yüksek ortalamanın tıbbi hizmetlere, en düşük ortalamanın ise yiyecek-içecek hizmetlerine ait olduğu tespit edilmiştir. Bu sonuçlar, termal turizm işletmelerine tedavi amaçlı gelenlere verilen tıbbi hizmetlerin iyi düzeyde olduğunu göstermekle birlikte, diğer hizmetler açısından kalitenin düşük olduğunu ortaya koymaktadır. Hizmetin bir bütün olduğu varsayımından hareketle, özellikle temizlik ve hijyen ile yiyecek-içecek hizmetleri konusundaki eksiklerin tamamlanması gerekmektedir. Termal turizm işletmelerine tedavi amaçlı gelenlerin, uzun süre konakladığı düşünüldüğünde, yiyecek içecek çeşitliliği ve kalitesinin arttırılması, hastalıklara uygun diyet yemeklerin sunulması, yemeklerin içerik ve besin değerleri konusunda prospektüs oluşturulması müşterilerin hizmet kalitesi algısını olumlu etkileyecektir.

Araştırmadan elde edilen en önemli bulgulardan biri, hizmet kalitesinin pozitif duyguları ve tekrar ziyaret niyetini olumlu, negatif duyguları ise olumsuz etkilemesidir. Bu bulgular daha önce başka alanlarda yapılan araştırmalarla benzerlik göstermektedir (Bigné vd., 2008; Rojas ve Camarero, 2008). Hizmet kalitesinin artmasının, pozitif duyguları ve tekrar ziyaret niyetini, yüksek düzeyde olumlu etkilediği ancak negatif duygular üzerindeki etkisinin daha düşük olduğu belirlenmiştir.

Araştırma bulguları, müşterilerin tekrar ziyaret niyetini en çok etkileyen unsurun pozitif duygular olduğunu göstermektedir. Elde edilen bulgular, Lo vd., (2015) tarafından SPA müşterileri üzerinde yapılan çalışmanın sonuçlarıyla örtüşmektedir. Söz konusu çalışmada, hizmet kalitesi boyutlarının pozitif duyguları, pozitif duyguların da gelecek davranışlarını etkilediği belirtilmektedir.

Araştırmadan elde edilen bulgular, termal turizm açısından müşteriye sunulan hizmet kalitesinin önemli olduğunu göstermekle birlikte, sunulan hizmetin müşteride yarattı̆̆ı duygusal tepkilerin, hizmet kalitesinden çok daha önemli olduğunu ortaya koymaktadır. Dolayısıyla termal turizm işletmelerinin müşterilerine pozitif duygularını uyaracak, farklı ve benzersiz deneyimler yaşatması gerekmektedir. Bunun için konaklama süresi boyunca müşterilerin zevk almalarını, rahatlamalarını, keyifli zaman geçirmelerini ve mutlu hissetmelerini sağlayacak aktiviteleri hayata geçirmeleri faydalı olacaktır. Özellikle animasyon faaliyetleri, konser, yarışma, sağlık uzmanları ya da sağlığına kavuşmuş hastalarla yapılacak söyleşi ve etkinlikler müşterilerin moral ve motivasyonunu arttıracaktır. Ayrıca fiyatlarda indirim yapmak, hediye ve indirim kuponu vermek müşterilerin kendilerini özel hissetmesini sağlayacak ve pozitif duygularını teşvik edecektir.

Restoran işletmelerinde, tüketim duygularını inceleyen araştırmalar, işletme atmosferinin pozitif duyguları olumlu etkilediğini ortaya koymaktadır (Jang ve Namkung 2009; Walsh vd., 2011). Benzer biçimde, termal turizm işletmelerinde de, görsel çekicilik, çevre düzenlemesi, estetik, sağlıklı ışıklandırma, rahatlatıcı renkler, özel kokular ve rahatlatıcı müzik yayınları gibi duyulara hitap eden unsurların kullanılması müşterilerde pozitif duyguların oluşmasını sağlayacaktır. Negatif duyguların azaltılması için yapılması gereken en önemli şey ise çalışanların sorun çözme, iletişim becerileri ve empati duygularının geliştirilmesidir. Çalışanların, özellikle tedavi amacıyla gelenlerin psikolojik durumlarını göz önünde bulundurarak sabırlı, güler yüzlü ve iyi niyetli yaklaşımları, müşterilerin negatif duygularını büyük ölçüde engelleyecektir.

Literatür taramasında benzer araştırmaların daha çok hizmet kalitesi, müşteri beklentileri ve müşteri memnuniyetine odaklandığı gözlenmiştir. Bu araştırmanın diğerlerinden farkı, hizmet kalitesi ve tekrar ziyaret niyetinin tüketim duyguları ile birlikte ele alınmış olmasıdır. Bu noktada araştırmanın literatüre ve termal işletme yöneticilerine katkı sağlayacă̆ı öngörülmektedir.

Araştırmanın yalnız yerli müşteriler üzerinde, az sayıda otel işletmesinde ve belirli bir zaman diliminde yapılmış olması, araştırma sonuçlarının genellenmesini engelleyen önemli bir kısıt 
olarak değerlendirilmektedir. Bundan sonra, yapılacak araştırmaların yabancı turistler üzerinde ve farklı bölgelerde tekrarlanması önerilebilir. Hatta termal ve resort otel müşterilerinin karşılaştırılmasına dayalı çalışmaların, konuya yeni boyutlar kazandıracağı ve literatüre daha fazla katkı sağlayacağı düşünülmektedir.

\section{KAYNAKÇA}

Aşık, N. Akşit (2016). Algılanan Hizmet Kalitesinin Müşteri Memnuniyeti Üzerine Etkisi: Termal Otellerde Bir Araştırma, Journal of International Social Research, 9(47): 1161-1168.

Albayrak, A. ve Örnek, E. (2017). Müşterilerin Yalova-Armutlu'da Yer Alan Termal Tesislerden Memnuniyet Düzeyi ve Tekrar Ziyaret Niyetleri. 62: 295-315.

Alén, M., Fraiz, J. A. and Rufín, R. (2006). Analysis of Health SPA Customers Expectations and Perceptions: The Case of Spanish Establishments, Tékhne-Revista de Estudos Politécnicos, (5-6): 245262.

Alexandris, K., Kouthouris, C. and Meligdis, A. (2006). Increasing Customers' Loyalty in a Skiing Resort: The Contribution of Place Attachment and Service Quality, International Journal of Contemporary Hospitality Management, 18(5): 414-425.

Ataman, G., Kartaltepe B. N. ve Eşgi S. (2011). İş Amaçlı Havayolu Pazarında Hizmet Kalitesinin SERVQUAL Modeli İle Ölçülmesi ve Türk Hava Yolları “Business Class" Yolcuları Üzerine Bir Araştırma, Selçuk Üniversitesi SBE Dergisi, 26: 73-87.

Bigné, J. E., Mattila, A. S. and Andreu, L. (2008). The Impact of Experiential Consumption Cognitions and Emotions on Behavioral Intentions. Journal of Services Marketing, 22 (4): 303-315.

Chen, Y., Lehto, X. Y. and Choi, S. (2009). Effect of Experience on Cognition, Affect and Satisfaction: The Case of Japanese Visitors to Macau, Journal of Hospitality Marketing and Management, 18(2-3): 273-293.

Chi, C. G. Q. and Qu, H. (2008). Examining The Structural Relationships of Destination Image, Tourist Satisfaction and Destination Loyalty: An Integrated Approach, Tourism Management, 29(4): 624-636.

Cho, B. H., Lee, C. and Chon, T. J. (2004). Effect of Customers' Service Quality Satisfaction for Repurchase of Golf Range User, Korean Journal of Physical Education, 42(2): 179-188.

Cronin Jr, J. J., Brady, M. K. and Hult, G. T. M. (2000). Assessing the Effects of Quality, Value, and Customer Satisfaction on Consumer Behavioral Intentions in Service Environments, Journal of Retailing, 76(2), 193-218.

Çatı, K. ve Baydaş, A. (2008). Hizmet Pazarlaması ve Hizmet Kalitesi, Ankara: Asil Yayın Dağııı.

Duman, T. ve Öztürk, A. B. (2005). Yerli Turistlerin Mersin Kızkalesi Destinasyonu ve Tekrar Ziyaret Niyetleri İle İlgili Algılamaları Üzerine Bir Araştırma. Anatolia: Turizm Araştırmaları Dergisi, 16(1): 9-23.

http://www.balikesirkulturturizm.gov.tr/TR,208784/isletme-bel geli-konaklama-tesisleri-html. [Erişim Tarihi: 11.02.2018]

Jang, S. S. and Feng, R. (2007). Temporal Destination Revisit Intention: The Effects of Novelty Seeking and Satisfaction. Tourism Management, 28(2): 580-590. 
Jang, S.C. (Shawn) and Namkung, Y. (2009). Perceived Quality, Emotions, and Behavioral Intentions: Application of an Extended Mehrabian-Russell Model to Restaurants, Journal of Business Research, 62: 451-460.

Kalaycı, Ş. (2014). SPSS Uygulamalı Çok Değişkenli İstatistik Teknikleri, Ankara: Asil Yayın Dağıtım.

K1lıç, B. ve Eleren, A. (2009). Turizm Sektöründe Hizmet Kalitesi Ölçümü Üzerine Bir Literatür Araştırmasi, Alanya İşletme Fakültesi Dergisi, 1(1): 91-118.

King, S., C. and Meiselman, H., L. (2010). Development of a Method to Measure Consumer Emotions Associated with Foods, Food Quality and Preference, 21(2): 168-177.

Lo, A., Wu, C. and Tsai, H. (2015). The Impact of Service Quality on Positive Consumption Emotions in Resort and Hotel SPA Experiences, Journal of Hospitality Marketing and Management, 24(2): 155-179.

Matilla, A.S. and Ro, H. (2007). Discrete Negative Emotions and Customer Dissatisfaction Responses in a Casual Restaurant Setting, Journal of Hospitality and Tourism Research, 32(1): 89-107.

Murat, G. ve Çelik, N. (2007). Analitik Hiyerarşi Süreci Yöntemi İle Otel İşletmelerinde Hizmet Kalitesini Değerlendirme: Bartın Örneği, Uluslararası Yönetim İktisat ve İşletme Dergisi, 3(6): 1-20.

Organ, A. ve Soydaş, M. E. (2012). Yerli Turistlerin Hizmet Kalitesi ve Tekrar Ziyaret Niyetlerine Yönelik Tutumları: Karahayıt'ta Bir Uygulama, Pamukkale Üniversitesi Sosyal Bilimler Enstitüsü Dergisi, (12): 63-72.

Phillips, D. M. and Baumgartner, H. (2002). The Role of Consumption Emotions in the Satisfaction Response, Journal of Consumer Psychology, 12(3): 243-252.

Richins, M. L. (1997). Measuring Emotions in the Consumption Experience, Journal of Consumer Research, 24(2): 127-146.

Rojas, C. and Camarero, C. (2008). Visitors' Experience, Mood and Satisfaction in a Heritage Context: Evidence from an Interpretation Center, Tourism Management, 29(3): 525-537.

Timur, B. (2015). Termal Turizmde Hizmet Kalitesi, Algllanan Destinasyon Imajı ve Tekrar Ziyaret Niyeti Arasındaki İlişkilerin İncelenmesi, Yayınlanmamış Yüksek Lisans Tezi, Osmangazi Üniversitesi, Sosyal Bilimler Enstitüsü, Eskişehir.

Türksoy, A. ve Türksoy, S. S. (2010). Termal Turizmin Geliştirilmesi Kapsamında Çeşme İlçesi Termal Kaynaklarının Değerlendirilmesi, Ege Akademik Bakış, 10(2): 701-726.

Walsh, G., Shiu, E., Hassan, L. M., Michaelidou, N. and Beatty, S. E. (2011). Emotions, StoreEnvironmental Cues, Store-Choice Criteria, and Marketing Outcomes, Journal of Business Research, 64(7): 737-744. 